\title{
Prevalence of hepatitis B surface antigen in rural area in Mosul city
}

\author{
Mahmood Y TAHA* \\ Mohamed Kh HASOUNI** \\ Tariq M QASIM ***
}

\begin{abstract}
The prevalence of $\mathrm{HBs}$ antigen in (400) healthy people in rural area in Mosul was (5\%). A high incidence of $\mathrm{HBs}$ was seen in young age group $(25-34)$ years $(11.69 \%)$ and in males $(7.15 \%)$ more than females $(3.64 \%)$. The high incidence of $\mathrm{HB}$ infection suggests that the dentist should take the preventive measures of being infected by their patients.
\end{abstract}

Key Words: Hepatitis, antigen, prevalence.

\section{الخلاصة}

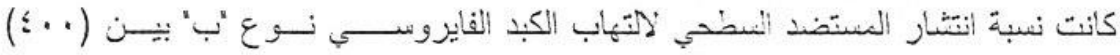

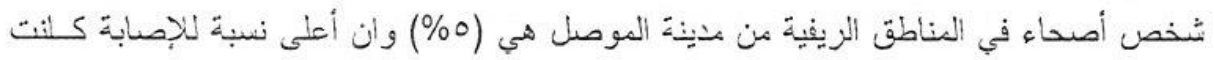

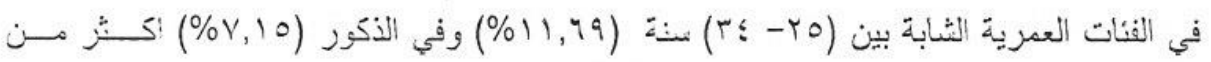

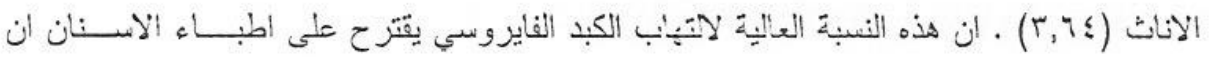

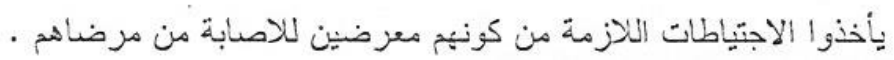

* Mahmood Younis TAHA; BVM\&S, MSc. PhD. MlB: Assistant Prof. Department of Basic Sciences, College of Dentistry, University of Mosul, Mosul, IRAQ.

**Mohamed Khalil HASOUNI; BDS, FDS RCPS: Lecturer. Department of Oral and Maxillofacial Surgery, College of Dentistry, University of Mosul, Mosul, IRAQ.

***Tariq Mahmood QASIM; BSc, MSc: Lecturer. College of Pharmacy, University of Mosul, Mosul, IRAQ. 


\section{INTRODUCTION}

Hepatitis $B$ infection is caused by hepatitis (HBV), a DNA hapadanavirus, which is a complex virus. The virus is mainly hepatotropic leading to persisting infection causing active chronic hepatitis and hepatocellular carcinoma ${ }^{(1)}$. The virus is transmitted through infected blood and blood products ${ }^{(2.3)}$. Other sources like saliva has been reported ${ }^{(4)}$.

The prevalence of HBV varies greatly between different parts of the world ${ }^{(5)}$. A high incidence being reported in Africa and Asia countries than in American, Australia, and Western Europe ${ }^{(2.5)}$. There is tendency toward high prevalence in men than women ${ }^{(6,7)}$. However, in developed countries the risk of exposure to $\mathrm{HB}$ appears to be greater in certain people ${ }^{(8)}$.

The importance of $\mathrm{HB}$ in dentistry has been focused by several reports particularly in view of serious sequelae of the disease and the potential risk of transmission of the infection to dentists. It has been reported that $\mathrm{HB}$ carriers among dentists were (10-20) times more than in general population (9). Therefore, it is important to the dentists to inform about the risk of being infected by their patients.

Most of the epidemiological studies have been carried out in urban area of Iraq on health care staff ${ }^{(10-12)}$. The present study extends these investigations and study the prevalence of $\mathrm{HBV}$ among healthy people who lived in Rural area (Qabir Al-Abid village) in the south of Mosul from which we can evaluate the risk of HBV infection to our staff.

\section{MATERIALS AND METHODS}

\section{Blood Collection and Data}

The work was conducted as apart of the college plan to provide dental management and treatment to people in the village around Mosul city. Venous blood was collected randomly in plane tube from 400 healthy people (140 males and 260 Females) living in the village of Qabir Al-Abid in Mosul city. Sera were separated and stored at $(-20) C^{\circ}$ until the time of assay. Data of age, sex, occupation, history of jaundice, previous surgical 
operation, history of blood transfusion, parenteral drug intake were obtained directly from the people.

\section{Serological Test}

Detection of serum $\mathrm{HBs}$ antigen was done by ELISA test (hepanostika, HBs A Uni - Form, Organon Teknika). The test is an enzyme immunoassay based on one step sandwich principle.

\section{RESULTS}

\section{Prevalence of HBs Antigen in Relation to Sex and Age}

The age range of people involved in this study was (10-55) years. HBs antigen was detected in (20) people out of (400) $(5 \%)$. HBs antigen was seen more in the age group (25-35) years of both sexes (table 1). The occupations of the people were (47.5\%) farmers, $(35 \%)$ housewives, $(10 \%)$ students and $(7.5 \%)$ unemployed. The ratio of female to male was $(.1 .85: 1)$. $\mathrm{HBs}$ antigen was detected more in male $(7.15 \%)$ than in female $(3.46 \%)$

Table (1): Prevalence of $\mathrm{HBs}$ antigen in relation to age

\begin{tabular}{|c|c|c|}
\hline 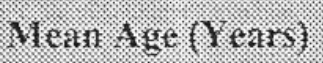 & No. 1 estag & 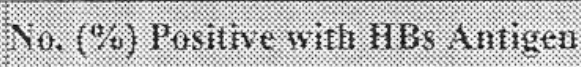 \\
\hline $15-24$ & 102 & $2(1.96)$ \\
\hline $25-34$ & 118 & $12(11.69)$ \\
\hline $35-44$ & 77 & $4(5.19)$ \\
\hline $45-54$ & 56 & $2(3.57)$ \\
\hline Above 55 & 47 & $0(0)$ \\
\hline
\end{tabular}

Prevalence of HBs Antigen in Relation to Previous History of Jaundice, Blood Transfusion, Parenteral Drug Intake and Surgical Operation

The prevalence of $\mathrm{HBs}$ antigen in relation to the above factors is shown in table (2). The people involved in this study were $(20 \%)$ with history of surgical operation, (12.5\%) with history of jaundice, $(5 \%)$ with 
history of blood transfusion, (47.5\%) with history of parenteral drug intake whether intravenous or intramuscular, and $(15 \%)$ with no history to the above factors. The total number of positive people for HBs antigen was (20), (40\%) of them had a history of hospitalization for different surgery, $(20 \%)$ with history of jaundice, (10\%) with history of blood transfusion, $(20 \%)$ with history of parenteral drug intake and $(10 \%)$ with no history to the above factors.

Table (2): Prevalence of HBs antigen in relation to the history of surgical operation, jaundice, blood transfusion and parenteral drug intake

\begin{tabular}{|c|c|c|}
\hline $\operatorname{li} a=1,010$ & 10. I ested: (70) & 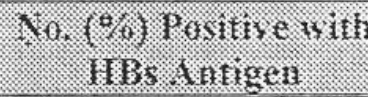 \\
\hline Surgical operation & $80(20)$ & $8(40)$ \\
\hline Jaundice & $50(12.5)$ & $4(20)$ \\
\hline Blood transfusion & $20(5)$ & $2(10)$ \\
\hline Parenteral drug intake & $190(47.5)$ & $4(20)$ \\
\hline No history & $60(15)$ & $2(10)$ \\
\hline Total & $400(100)$ & $20(100)$ \\
\hline
\end{tabular}

\section{DISCUSSION}

In spite of our increasing knowledge of the complex capacity of virus infection to influence cellular and organ functions, we still do not have an overall view of total medical importance of virus infection. ${ }^{(13)}$ Indeed, there is very reason to assume that continual change in the infectious diseases is to be expected in the future ${ }^{(14)}$. The infectivity and widespread epidemicity of virus infection and to the lack of specific therapy, makes prevention of viral disease most important. Such prevention is dependent on epidemiological study. Measures of general hygiene have some effect as seen by the variable incidence of HBV in different countries but vaccination represents the most practical and effective method for viral disease control. 
The use of virus vaccine should be decided with reference to the epidemiological conditions. The epidemiological occurrence of different viruses shows marked variations. These concern seasonal, geographical distribution as well as the occurrence of diseases in different ages, sexes and races ${ }^{(15)}$

Several epidemiological studies on the prevalence of $\mathrm{HBV}$ have been carried out in urban Area in Iraq ${ }^{(10,12,16,17)}$. Little is known about the prevalence of HBV in rural area.

The present study showed high incidence of HBV (5\%) in Qabir AlAbid village in Mosul, which is higher than those reported for Iraqi general population. Abdool et al. ${ }^{(18)}$. Showed high prevalence of $\mathrm{HBs}$ antigen in rural area in South Africa. Several Studies showed that the rate of HBV infection among health care staff was (10-20) time the rate in.general population ${ }^{(10,11,19,20)}$. A high incidence of HBV was among dentists who are in frequent contact with blood and saliva ${ }^{(21.24)}$.

A high incidence of $\mathrm{HBV}$ was observed in males $(7-15 \%)$ than females $(3.46 \%)$. Data of several epidemiological studies are consistent with this picture ${ }^{(7,25,26)}$. The exact cause of such sex difference in prevalence of HBV is not yet known. Females, however, have high rate of clearance of $\mathrm{HBs}$ antigen than males ${ }^{(27)}$. The peak of incidence of HBV was in young age group that then declined with old age. Boutim et al. ${ }^{(28)}$ and Damelio et al. (29) showed that high incidence of the HBV was among young adult. Several reports ${ }^{(8,30,31)}$ showed that the rate of seropositivity of HBs antigen increased with advancing age. Most of these studies have carried out on health care staff who are subjected to frequent exposure to HBV sources with extend years of employment. Our explanation that the incidence of HBV did not increase with old age is probably the social behavior of the people in rural area in which the young age group represents the active group who are in contact with people in cities whereas the older age groups maintain their styles of living in the village. A high incidence of HBV was observed in people with previous history of hospitalization (40\%) which indicated the possible rule of cross infection in the transmission of HBV.

The high incidence of HBV in rural area suggests that the dentists should take precautions of being infected by their patients. Such preventive include wearing gloves, masks, protective eye shield and frequent hand washing ${ }^{(32)}$. Improvement in the hygienic condition by using adequately sterilized and disinfected instruments and using disposable syringes and needles is important to reduce the risk of catching $\mathrm{HBV}^{(33)}$. 
The use of virus vaccine should be decided with reference to the epidemiological conditions. The epidemiological occurrence of different viruses shows marked variations. These concern seasonal, geographical distribution as well as the occurrence of diseases in different ages, sexes and races ${ }^{(15) \text {. }}$

Several epidemiological studies on the prevalence of HBV have been carried out in urban Area in Iraq ${ }^{(10,12,16,17)}$. Little is known about the prevalence of HBV in rural area.

The present study showed high incidence of HBV (5\%) in Qabir AlAbid village in Mosul, which is higher than those reported for Iraqi general population. Abdool et al. ${ }^{(18)}$. Showed high prevalence of HBs antigen in rural area in South Africa. Several Studies showed that the rate of HBV infection among health care staff was (10-20) time the rate in.general population ${ }^{(10,11,19,20)}$. A high incidence of HBV was among dentists who are in frequent contact with blood and saliva ${ }^{(21.24)}$.

A high incidence of HBV was observed in males (7-15\%) than females (3.46\%). Data of several epidemiological studies are consistent with this picture ${ }^{(7,25,26)}$. The exact cause of such sex difference in prevalence of $\mathrm{HBV}$ is not yet known. Females, however, have high rate of clearance of HBs antigen than males ${ }^{(27)}$. The peak of incidence of $\mathrm{HBV}$ was in young age group that then declined with old age. Boutim et al. ${ }^{(28)}$ and Damelio et al. ${ }^{(29)}$ showed that high incidence of the HBV was among young adult. Several reports ${ }^{(8,30,31)}$ showed that the rate of seropositivity of $\mathrm{HBs}$ antigen increased with advancing age. Most of these studies have carried out on health care staff who are subjected to frequent exposure to HBV sources with extend years of employment. Our explanation that the incidence of HBV did not increase with old age is probably the social behavior of the people in rural area in which the young age group represents the active group who are in contact with people in cities whereas the older age groups maintain their styles of living in the village. A high incidence of $\mathrm{HBV}$ was observed in people with previous history of hospitalization (40\%) which indicated the possible rule of cross infection in the transmission of HBV.

The high incidence of HBV in rural area suggests that the dentists should take precautions of being infected by their patients. Such preventive include wearing gloves, masks, protective eye shield and frequent hand washing ${ }^{(32)}$. Improvement in the hygienic condition by using adequately sterilized and disinfected instruments and using disposable syringes and needles is important to reduce the risk of catching $\mathrm{HBV}^{(33)}$. 


\section{REFERENCES}

1. Tiollais P, Pourcel C, Dejean A. The hepatitis B virus. Nature. 1985; 317: 498 .

2. Sherlock S. Prevention and treatment of virus hepatitis. Br Postgrad Doc Mid East. 1984; Jan: 49 - 56.

3. Barker LF, Shluman NR, Murry R, et al. Transmission of serum hepatitis. J Am Med Assoc. 1970; 211: 509-512.

4. Villarejos VM., Visona KA, Cutiene ZA, Rodriguez A. Role of saliva, urine and faeces in transmission of type B virus hepatitis. $N$ Eng JMed. 1974; 291: 1375.

5. Sobselavsky O. Prevalence of markers of hepatitis B virus infection in various countries: WHO Collaborative study. Bull WHO. 1980; 58: 621.

6. Takieddine

7. FN, Tafenkejs HT, Sheth KV, Gandour MH. Prevalence of HBV markers in adults saudi in relation to age and sex. Annals Saudi Med. 1986; 6: 205.

8. Franco E, Olivadese A, Valeri M, Albertoni F, Petrosille N. Control hepatitis B virus infection in dialysis units in Latium, Italy. Nephron. 1992; 61(3): $329-330$.

9. McQuillan GM, Townserd TR, Field AH, Carroll M, Leahy M, Polk BF. Seroepidemiology of hepatitis B virus infection in the United States, 1976 to 1986. Am JMed. 1989; 87 (3A): 5s - 10s.

10. Withers JA. Hepatitis. A review of the disease and its significance to dentistry. J Periodontol. 1980; 51: 162-166.

11. Omer AR, Al-Douri S. Viral hepatitis in Iraq. Proceeding of the $6^{\text {th }}$ International Congress of Virology. Sendi. Japan. 1984; Pp: 32.

12. Alwan AAS, Omer AR. Prevalence of hepatitis B surface antigen and anti - HBs in healthcare personnel in Baghdad. Arab JMed. 1986; 5(5): 46.

13. Mohamed HY. Prevalence of Hepatitis B, Delta viral infections among personnel in Mosul. MSc thesis submitted to the College of Medicine, Mosul University. 1987.

14. Norrby E, Lucke E. Viruses. A unique kind of infectious agents. In: Medical Virology. Wellington. 1983; Pp: 1.

15. Oxford JS, Oberg BO. Conquest for Viral Disease. 1983; Pp: 31.

16. Norrby E, Bottiger N. The epidemiology of viral disease. In: Medical Virology. Wellington. 1983; Pp: 234.

17. Shinhog B, Al-Kassab S. Hepatitis B antigen in Iraq. Lancet. 1973; 1: 1269. 
17. Al-Khishali TJ, Al-Shamma MTJ. Prevalence of hepatitis B surface antigen in Iraqi dental patients. Iraqi Dent J. 1990; 15: 1-3.

18. Abdool-Karim SS, Thejpal R, Singh B. High prevalence of hepatitis virus infection in rural black adults in Mseleni South Africa. Am J Pub Hlth. 1989; 79(7): 893-894.

19. Lewis T, Alter HJ, Chalmers CC, Holland PV, Purcell RH, Alling DW, Young D, Frenkel LD, Lee SL, Lamson ME. A Comparison of the frequency of hepatitis $B$ antigen and antibody in hospital and nonhospital personnel. N Eng JMed. 1973; 289: 51.

20. Gibas A, Blewett DR, Scoenfeld DA, Dienstage JL. Prevalence and incidence of viral hepatitis in health workers in the prehepatitis $B$ vaccination era. Am J Epidemiol. 1992; 136(5): 603-610.

21. Feldman RE, Schiff ER. Hepatitis in dental professionals. J Am Med Assoc. $1975 ; 232: 1228-1230$.

22. Hurlen B, Iversen B. Viral hepatitis in Oral Surgery and Periodontics in Norway. Int J Oral Surg. 1978; 8: 443-448.

23. Reingold AL, Kane MA, Murphy BL, Checko oral surgeon. Gastroenterol. 1982; 79: 893.

24. Panis B, Roumeliotou KA, Papaevangelou G, Richardson SC, Mitsis F. Hepatitis B virus infection in dentist and dental students in Greece. Oral Surg Oral Med Oral Pathol. 1986; 6: 34

25. Hadziyannis ST, Merikas GE, Panetosos S, Kourepi M. Hepatitis associated antigen carries among blood donors in Greece. Am JDis Child. 1972; 123: 381-383

26. Hovig B, Rollay H, Dahlo O. Antibody to hepatitis B surface antigen among employees in 12 national hospitals, Oslo, Norway. A prevalence study. Am J Epidemiol. 1985; 22: 127.

27. Alward WLM, McMahon BL, Hall DB. The long term serological course of asymptomatic hepatitis B virus carrier and the development of primary hepatocellular carcinoma. J Infect Dis. 1985; 151: 604.

28. Boutin JP, Sainte-Maric FF, Cardines R, Girard M, Roux J. Prevalence of hepatitis B virus infection in Austral archipelaggo, French polynesia: Identification of transmission patterns for the formulation of immunization strategies. Tran R Soc Trop Med Hyg. 1990; 84.(2): 283287.

29. Damelio R, Matricadi PM, Biselli R, Stroffolini T, Mele A, Spada E, Chionne P, Rapicetta M, Ferrigno L, Pasquini P. Changing epidemiology of hepatitis B in Italy: Public health implications. Am J Epidemiol. 1992; 135(9): 1012-1018. 
31. Janzen J, Trizpatzis J, Wagner V, Schlieter M, Muller DE, Wolters E. Epidemiology of hepatitis B Surface antigens ( $\mathrm{HBs} \mathrm{Ag}$ ) and antibody to HBs Ag in hospital personnel. J Infect Dis. 1978; 137: 261-266.

32. Struve J, Giesecke J, Olcen P, Von- Sydow M, Weiland O. Prevalence of hepatitis B virus markers in Sweden: A community based serosurvey of 4000 young Swedish adults. Am J Epidemiol. 1992; 135 (4): 409-417.

33. Scully C. Hepatitis B: An update in relation to dentistry. Br Dent J. 1985; 23: $321-328$.

33. Scully C. Hospital dental surgeon's guide. London, British Dental Association. 1985. 